Article

\title{
Lyophilized Probiotic Lactic Acid Bacteria Viability in Potato Chips and Its Impact on Oil Oxidation
}

\author{
Heba Mostafa \\ Food Science Department, Faculty of Agriculture, Cairo University, Giza 12613, Egypt; \\ Hebabiotech@agr.cu.edu.eg or Hebabiotech@gmail.com; Tel.: +02-010-022-108-22
}

Received: 2 April 2020; Accepted: 17 April 2020; Published: 5 May 2020

check for

updates

\begin{abstract}
To produce a new probiotic-containing food product, potato chips, as the most preferred fast food, were chosen. Preferably, it should be preserved for a long period without oxidation. The presented study aimed to compare potato chips containing two lyophilized probiotic lactic acid bacteria (Bifidobacterium longum ATCC 15708 and Lactobacillus helveticus LH-B02) in order to retard lipid oxidation. Lyophilization of probiotics was carried out into two cryoprotective media-skim milk (SM) and gelatin/glycerol (GG) as lactose-free medium. Results revealed that GG and SM media were the most suitable for lyophilization of B. longum and L. helveticus, respectively. The lyophilized live cells were incorporated in potato chips, packed and their effect on oil oxidation was assessed. Results showed that the lyophilized B. longum in SM remained alive at $6.5 \log \mathrm{CFU} / \mathrm{g}$ for 4 months at $30^{\circ} \mathrm{C}$. Interestingly, potato chip bags containing B. longum lyophilized in SM medium exhibited a decrease in peroxide value (PV) and acid value (AV) of the extracted oil by $40.13 \%$ and $25 \%$, respectively, compared to the control bags. The created probiotic potato chips containing B. longum fulfill the criteria of the probiotic product besides the prime quality and sensory attributes.
\end{abstract}

Keywords: probiotic potato chips; lactic acid bacteria lyophilization; cryoprotectant; antioxidation

\section{Introduction}

Today, with a busy lifestyle, individuals, especially young and adolescents, prefer to consume 'ready-to-eat' snack foods. The most popular and over-consumed product is potato chips, which are eaten as a snack food, side dish or appetizer. Potato chips may be consumed 3 times/week or more [1,2]. Potato chips are considered a starchy product (total carbohydrate in the range of 60-63.6\%) in addition to fat (33-40\%) and dietary fibers (1-1.6\%) [3-5]. Chips also provide other important micronutrients such as sodium $(480 \mathrm{mg} / 100 \mathrm{~g})$ and potassium $(166 \mathrm{mg} / 100 \mathrm{~g})$ [3]. Potato also contains a variety of phytonutrients, most notably carotenoids and phenolic acids, mainly chlorogenic acid [6,7].

By deep oil frying, potato chips absorb a considerable quantity of oil. The final fat content ranges from $35 \%$ to $38 \%$ based on the total weight [8]. These high oil levels are not only important for nutritional quality but also have a dominant influence on the flavor, calories supplied, and their shelf life [9]. High surface-to-volume ratio of potato chips results in oxidative deterioration of the stored product. Also, lipid oxidation can lead to changes in functional, sensory, and nutritive values that reduce consumer acceptability of the product [4]. As known, the consumption of oxidized oil leads to a variety of diseases, such as atherosclerosis and cancer [10]. The level of oxidation of the containing potato chips oil, and the concomitant formation of off-flavors, is ultimately assessed by some tests such as the peroxide value (PV), acid value (as free fatty acids) (AV) and levels of conjugated dienes (CD) formed during oxidation [11]. Different chemical and natural antioxidants have been examined to retard the lipid oxidation of fats and oils in processed foods $[4,12]$.

Probiotics are live microorganisms that, when administered in adequate amounts, confer health benefits to the host as defined by Food and Agriculture Organization/World Health Organization [13]. 
It was approved by Food and Drug Administration (FDA) as Generally Recognized as Safe (GRAS) [14]. Today, most commercially available probiotics belong to the genera Lactobacillus and Bifidobacterium. Many of them have already been used as probiotics in different dairy $[15,16]$ and nondairy products $[17,18]$. Besides their innumerous gut health effects, they showed many benefits such as antimicrobial activity, ability to modulate the immune response, gastrointestinal ecosystems improvement $[19,20]$ and anticancer activity [21]. Several in vitro studies have confirmed the strong antioxidant power of some probiotics, especially Bifidobacterium longum and Lactobacillus helveticus strains [10]. As examples, Lactobacillus helveticus in skim milk showed considerably strong antioxidant activity (62.32\%) measured using O-phthaldialdehyde, 2, 2-diphenyl-1-picrylhydrazyl (DPPH) reagent [22]; bovine skim milk fermented by selected L. helveticus 474 strain showed high free radical (1,1-diphenyl-2-picrylhydrazyl) scavenging activity [23]. Also, whey protein isolates hydrolyzed by Lactobacillus helveticus T80 fermentation had strong antioxidant activity [24]. Encapsulated Bifidobacterium longum KACC 91,563 caused the least lipid oxidation level when used in sausage fermentation by Song et al. [25] in comparison with cell-free sausages. In addition, those two strains have beneficial antiobesity effects with different mechanisms, i.e., reduced lipid accumulation, lowering high-fat-diet-elevated lipopolysaccharide levels in blood and/or insulin resistance and hepatic steatosis formation. An excellent example demonstrating the potential of probiotics for fats reduction is represented by An and coworkers [26] who investigated the antiobesity and lipid-lowering effects of Bifidobacterium longum SPM 1205 and 1207 strains on high-fat-diet-induced obese rats. In addition, four Bifidobacteria (L75-4, M13-4 and FS3-1-1-2) strains showed a role in reducing serum and liver triglyceride and total cholesterol, as well as liver lipid deposition as reported by Yin et al. [27]. Plasma lipopolysaccharide was normalized to the control levels in the high-fat Bifidobacterium longum-treated rats [28]. A study by Arigoni et al. [29] also demonstrated the effect of Lactobacillus helveticus CNCM I-4095 strain in supporting weight management, which promoted weight loss by $15 \%$ after 40 days of administration and could be used to treat obesity.

Foods containing probiotic microorganisms are expected to have a promising future. The challenge is to maintain the viable cultures in the final product for the longest period. Freeze-drying (lyophilization or cryodesiccation) is the most commonly used technique for probiotic culture dehydration to stabilize probiotics in functional foods [30]. Freeze-drying involves the dehydration by sublimation of frozen ice present within the molecules. It is a preferred method for compounds that are thermally sensitive and prone to oxidation, since it operates under a high vacuum and at low temperatures [31]. Lyophilized probiotic bacteria have been extensively used for pharmaceutical applications [32] and foodstuffs such as sausages [33], soy bars [34], apple snacks [35] and many dairy products [36-38]. Chocolate, as the most consumed candy, although it is rich in fats and sugars, has also been tested as a carrier for lyophilized probiotics. For example, lyophilized Lactobacillus casie and paracasie maintained live at $10^{6}-10^{8} \mathrm{CFU} / \mathrm{g}$ in milk chocolate for 1 year [39]. The viability of probiotic Lactobacillus helveticus bacteria $\left(2.42 \times 10^{8} \mathrm{CFU} / \mathrm{g}\right)$ in chocolate was achieved only up to 15 days of storage at $10 \pm 2{ }^{\circ} \mathrm{C}$ [40], while Lactobacillus plantarum showed high stability in chocolate for 6 months [41]. However, the application of lactic acid bacteria and their physiological effect on potato chips has not yet been reported.

Given that potato chips are widely consumed around the world and the recent trend towards foods supplemented with live probiotics, this study was performed. Two probiotic lactic acid bacteria Bifidobactrium longum and Lactobacillus helveticus were chosen for the production of probiotic chips for their proved antioxidation and antiobesity effects [24-29]. First, this study aims to select the most appropriate protective media for probiotic lactic acid bacteria lyophilization. Second, it aims to investigate the effect of the lyophilized probiotic addition on the quality of potato chips and the shelf life of the stored product. 


\section{Materials and Methods}

\subsection{Raw Materials}

Fresh potato (Solanum toberosum var. Cara) was purchased from the local market, Giza Governorate, Egypt. Its chemical composition is shown in Table 1. Refined sunflower oil was obtained from Arma Company for food products (10th Ramadan City, Egypt). It has the following profile (\%): linoleic acid, 59; oleic acid, 30; stearic acid, 6; palmetic acid, 5 and vitamins A, D and H. Skim milk was purchased from Lamar Company for dairy products (Nubaria City, Egypt). All the used chemicals were fine analytical chemicals.

Table 1. Chemical analysis of potato Solanum toberosum var. Cara.

\begin{tabular}{cc}
\hline Component & Mean (\%) \pm SD \\
\hline Moisture & $73.83 \pm 0.83$ \\
Protein & $5.75 \pm 0.02$ \\
Fat & $1.24 \pm 0.06$ \\
Total carbohydrate & $13.88 \pm 0.15$ \\
Reducing sugar & $0.27 \pm 0.02$ \\
Crude fiber & $2.70 \pm 0.02$ \\
Ash & $2.85 \pm 0.87$ \\
\hline
\end{tabular}

\subsection{Potato Chips Preparation and Frying}

Potatoes were washed, peeled, and then sliced into chips (1.2 $\mathrm{mm}$ thickness). For more crispness, they were soaked in $\mathrm{CaCl}_{2}(1 \%)$ for $10 \mathrm{~min}$. A known amount (c. $2 \mathrm{~kg}$ ) of refined sunflower oil was placed in a stainless steel pan fryer $(50 \mathrm{~cm}$ diameter $x 20 \mathrm{~cm}$ height $)$ and heated at $180 \pm 5^{\circ} \mathrm{C}$. The chips were deep oil fried for $5 \mathrm{~min}$, drained to remove excess oil, then cooled [42].

\subsection{Probiotic Lactic Acid Bacteria}

Two probiotic lactic acid bacteria were used in this study. Bifidobactrium longum ATCC 15708 that was obtained from American Culture Collection, Manassas, VA, USA, and Lactobacillus helveticus LH-B02 (Chr. Hansen Laboratory Ireland Ltd., Little Island, Cork, Ireland). Stock cultures were stored at $-20{ }^{\circ} \mathrm{C}$ in de Man, Rogosa and Sharpe (MRS) broth (Merck, Darmstadt, Germany) containing glycerol $(20 \%)$. Working cultures were maintained anaerobically in MRS broth at $4{ }^{\circ} \mathrm{C}$ and were transferred to a new medium every month.

\subsection{Probiotic Lactic Acid Bacteria Production}

The lactic acid bacteria cells were prepared (before lyophilization) following procedures previously described [43] with minor adaptations. Two cryoprotective media were tested in this study. Skim milk (SM) medium contained 10\% skim milk + 5\% sucrose while, gelatin/glycerol (GG) medium (lactose free) contained 1.5\% gelatin + 1\% glycerol (from Sigma Aldrich Co.,Saint Louis, MO, USA). One hundred ml of fresh MRS was inoculated with $2.5 \mathrm{~mL}$ of maintained MRS broth culture and incubated anaerobically at $37^{\circ} \mathrm{C}$ for $48 \mathrm{~h}$ in an Anaerobe Jar. Subsequently, the obtained inoculum was used to inoculate the bottle of MRS (containing $400 \mathrm{~mL}$ ) and further incubated anaerobically at $37^{\circ} \mathrm{C}$ for $24 \mathrm{~h}$ (stationary phase). Cells were harvested by centrifugation (Hermle, Z300, Gosheim, Germany) at 11,000× $g$ for 5 min at $4{ }^{\circ} \mathrm{C}$, then washed 3 times with sterilized distilled water. After this, the supernatant was discarded, and the harvested cells were resuspended (final viable counts in the range of $7-8 \log \mathrm{CFU} / \mathrm{mL}$ ) in $100 \mathrm{~mL}$ of SM medium. The same procedures were repeated, but the harvested cells were resuspended in $100 \mathrm{~mL}$ of GG medium. All the resuspended cells were frozen to $-20^{\circ} \mathrm{C}$ before the lyophilization. 


\subsection{Lyophilization and Survival Test}

The frozen suspensions were dried-frozen (temperature $-40 \pm 2{ }^{\circ} \mathrm{C}$; vacuum pressure $10^{-1}$ torr for $48 \mathrm{~h}$ ) using a bench-top lyophilizer (Modulyo bench top freeze dryer, Edwards, Burgess Hill, UK). Viable cell counts were checked after freeze drying and in packed probiotic potato chips at different storage intervals (zero, 1, 2, 3 and 4 months) by the standard plate count method. For this, the dried powder or fried chips was aseptically rehydrated in sterile saline solution $(\mathrm{NaCl}, 0.85 \%)$ at room temperature for $10 \mathrm{~min}$. One $\mathrm{ml}$ aliquots were serially diluted and plated; then, MRS agar medium was poured. After incubation for $2-3$ days at $37^{\circ} \mathrm{C}$ under anaerobic conditions, the colonies were counted and results were expressed as $\log \mathrm{CFU} / \mathrm{g}$ [44].

\subsection{Probiotic Potato Chips Production and Storage Condition}

Potato chips immediately after frying and cooling were pooled together and packaged in $20 \times 10 \mathrm{~cm}$ polyethylene bags. Each bag was filled with chips $(4.5 \pm 0.2 \mathrm{~g})$ and lyophilized lactic acid bacteria powder that sticks on the surface of potato chips in the final cell count $\left(10^{9}-10^{10} \mathrm{CFU} / \mathrm{g}\right)$, vacuumed and heat-sealed then stored at room temperature $30 \pm 2{ }^{\circ} \mathrm{C}$ in a dark place for 4 months. Bags containing potato chips with no lactic acid bacteria were used as a control. Bags were removed from the storage carton monthly and the lactic acid bacteria viability was assessed as previously described.

\subsection{Chemical Analysis}

Chemical analysis of fresh potato (moisture, protein, fiber, fat and ash) was carried out according to A.O.A.C [45]. Total carbohydrates were determined by the Anthrone method [46] (after $\mathrm{HCl}$ hydrolysis, $2.5 \mathrm{~N}$ for $3 \mathrm{~h}$ ), while reducing sugar content was determined by the 3, 5-Dinitrosalicylic acid test (after extraction by hot ethanol solution, $80 \%$ ) [47].

After the storage period (the fourth month), the stored probiotic chips from 3 bags from each experiment were crushed and weighted. The oil content was determined using the Soxhlet apparatus. Lipid extraction was performed by chloroform/methanol mixture (1:1) as described by Petukhov et al. [42]. Peroxide value (PV) of extracted oil was determined according to Paquot [48] method II.D.13. Briefly, the sample is treated with a mixture of glacial acetic acid and chloroform then with a saturated potassium iodide solution. The liberated iodine is titrated with a standard solution of sodium thiosulfate $(0.05 \mathrm{~N})$ and expressed as meq $\mathrm{O}_{2} / \mathrm{kg}$. Free fatty acid percent (acid value, AV) was determined as described by Atalay and Inanc [49] by titration with $\mathrm{KOH}(0.05 \mathrm{~N})$ in the presence of phenolphthalein and expressed as Oleic acid. Each analysis was performed in triplicate.

\subsection{Sensory Evaluation}

An untrained panel of students and staff members $(n=20)$ at Food Science Department, Faculty of Agriculture, Cairo University evaluated the samples monthly for different sensory attributes such as taste, odor, color, appearance, texture and overall acceptance (using a 9-point hedonic scale). Samples were evaluated for their all sensory attributes where 9 and 1 represented liked extremely and disliked extremely, respectively [8].

\subsection{Statistical Analysis}

Experiments were conducted in triplicate and data were analyzed using the CoStat Microsoft program. Significant differences among means $(n=3)$ were determined by one-way ANOVA, using Duncan's test at $p<0.05$. 


\section{Results and Discussion}

\subsection{Survival of Probiotic Lactic Acid Bacteria}

Probiotics, being live microorganisms, have a great difficulty being incorporated and still living at the time of food product consumption. Therefore, choosing the right strains, culture conditions, and cryoprotectants should be considered. Protective agents such as skim milk, whey, trehalose, glycerol, sucrose, and glucose are commonly employed to protect bacterial cultures [30]. To preserve lactic acid bacteria during the lyophilization process, two media (i.e., SM and GG) were evaluated as cryoprotectants. The cell viability before and after the lyophilization process are shown in Table 2. It can be observed that the GG medium was better for protecting Bifidobacterium longum after lyophilization, as $79.03 \%$ of its initial population was still live. On the other hand, Lactobacillus helveticus lost $66.66 \%$ of its viability after lyophilization in SM medium. GG medium had a significant negative effect in the decline of its viability by $92.28 \%$. Lyophilization can cause many negative effects on the cells, such as a disruption of the cell walls resulting from the water vapor transportation to the surface of the sample for sublimation, collapse of protein and shrinkage [31]. Sharma et al. [50] reported skim milk as cryoprotectant for Streptococcus thermophilus strain. However, for Lactobacillus strains lyophilization, Yeo et al. [44] recommended a mix of $10 \%$ skim milk and $10 \%$ sucrose with $2.5 \%$ sodium glutamate.

Table 2. Viability of probiotic lactic acid bacteria (LAB) as affected by lyophilization (means \pm standard deviation (SD)).

\begin{tabular}{|c|c|c|c|c|}
\hline \multirow{2}{*}{$\begin{array}{c}\text { Lactic Acid } \\
\text { Bacteria }\end{array}$} & \multirow{2}{*}{$\begin{array}{l}\text { Cryo-Protective } \\
\text { Medium * }\end{array}$} & \multicolumn{2}{|c|}{ Cell Viability (Log CFU/g) } & \multirow[b]{2}{*}{ Viability Loss (\%) } \\
\hline & & $\begin{array}{c}\text { Before } \\
\text { Lyophilization }\end{array}$ & $\begin{array}{c}\text { After } \\
\text { Lyophilization }\end{array}$ & \\
\hline \multirow{2}{*}{ B. longum } & SM & $9.22 \pm 0.016$ & $8.96 \pm 0.033$ & $44.68^{c}$ \\
\hline & GG & $9.21 \pm 0.014$ & $9.11 \pm 0.047$ & $20.97^{\mathrm{a}}$ \\
\hline \multirow{2}{*}{ L. helveticus } & SM & $9.02 \pm 0.029$ & $8.82 \pm 0.060$ & $36.66^{b}$ \\
\hline & GG & $9.01 \pm 0.020$ & $7.91 \pm 0.007$ & $92.28^{d}$ \\
\hline
\end{tabular}

* SM: $10 \%$ skim milk $+5 \%$ sucrose, or GG: $1.5 \%$ gelatin $+1 \%$ glycerol. ${ }^{\text {a-d }}$ Means within rows with different superscripts differ significantly $(p<0.05)$.

Probiotic potato chips as a new probiotic product were assessed. The mean values of lyophilized probiotic cell viability in packed potato chips during storage for 4 months are represented in Table 3 . Viability of lyophilized Bifidobacterium longum strain in SM medium gradually decreased (with a significant difference $p<0.05$ ) but still maintained at $6.5 \log$ CFU/g for 120 days. In contrast, in GG medium, departing from $10.14 \log$ CFU/g, it decreased to $7.65 \log$ CFU/g (99.67\% loss) after 2 months of storage, then its viability was completely lost. With $10^{6}-10^{7} \mathrm{CFU} / \mathrm{g}$, potato chips containing $B$. longum lyophilized in SM medium are considered as a probiotic product because it is the standard limit accepted for probiotic products to be delivered to the consumers at the shelf-life end [16]. In the case of Lactobacillus helveticus strain, in SM medium, the viability decreased reaching $10^{4} \mathrm{CFU} / \mathrm{g}$ after the storage for four months. On the other side, it could not survive over one month in GG medium. It could be concluded that, under vacuum and high-oil content (potato chips) conditions, skim milk medium could protect both strains for 4 months compared to GG medium. That is supported by the previous results (Table 2), as GG medium caused the highest viability reduction of L. helveticus after the lyophilization step. The presence of milk solids is responsible of the difference of the two cryoprotectants during the storage with potato chips. The high nutrient content of milk might support their growth. Also, lactose, the principal sugar in milk, triggers the production of the inducible enzyme $\beta$-galactosidase, which sustains LAB growth [51]. In addition, cryoprotectants rich in amino acids and fermentable sugars (lactose and sucrose) can stabilize the lipid bilayer structure of the cell membrane in the absence of water [16]. Bifidobacterium longum viability in SM was higher than those reported by Nebesny et al. [52], who maintained lyophilized Lactobacillus in chocolate at 5 log CFU/g for 5 months storage at $30^{\circ} \mathrm{C}$. However, Bifidobacterium thermophiles NCIMB 702,554 maintained viability at 
$7.3 \log \mathrm{CFU} / \mathrm{g}$ for 90 days at $25^{\circ} \mathrm{C}$ [53]. While Guergoletto [25] maintained viable Lactobacillus casei in chocolate bars at $8.3 \log \mathrm{CFU} / \mathrm{g}$ for 84 days at $25^{\circ} \mathrm{C}$, Mirkovic et al. [54] maintained encapsulated L. plantarum $299 \mathrm{v}$ in dark chocolate at $10^{8} \mathrm{CFU} / \mathrm{g}$ up to 6 months at $20^{\circ} \mathrm{C}$. In another probiotic product, soy protein bars, freeze-dried microcapsules of Lactobacillus acidophilus LA-2 remained in high number throughout 14 weeks at $4{ }^{\circ} \mathrm{C}$ [34]. In contrast, in probiotic Lactobacillus plantarum-enriched apple snacks dried by microwave-vacuum, the probiotic bacteria remained above $1 \times 10^{6} \mathrm{CFU} / \mathrm{g}$ for 120 days at $25{ }^{\circ} \mathrm{C}$ [35]. Furthermore, freeze-dried immobilized L. casei ATCC 393 cells on casein were detected in yogurt at levels $>7 \log \mathrm{CFU} / \mathrm{g}$ after cold storage for 28 days [38].

Table 3. Viability of lyophilized probiotic lactic acid bacteria (LAB) in the stored potato chips.

\begin{tabular}{cccccc}
\hline \multirow{2}{*}{$\begin{array}{c}\text { Potato Chips } \\
\text { Containing LAB } \\
\text { Samples }\end{array}$} & $\mathbf{0}$ & $\mathbf{5}$ Time (Month) \\
\cline { 2 - 6 } & \multicolumn{5}{c}{ Cell Viability (Log CFU/g) } \\
\cline { 2 - 6 } & $*^{\mathrm{C}}$ & $\mathbf{2}$ & $\mathbf{3}$ \\
\hline B. longum in SM $\mathrm{a}$ & $* 10.20^{\mathrm{bA}} \pm 0.03$ & $10.15^{\mathrm{aB}} \pm 0.00$ & $9.55^{\mathrm{aC}} \pm 0.07$ & $7.81^{\mathrm{aD}} \pm 0.02$ & $6.50^{\mathrm{aE}} \pm 0.04$ \\
B. longum in GG & $10.14^{\mathrm{bA}} \pm 0.04$ & $9.22^{\mathrm{bB}} \pm 0.03$ & $7.65^{\mathrm{bC}} \pm 0.01$ & $0.00^{\mathrm{cD}} \pm 0.00$ & $0.00^{\mathrm{cD}} \pm 0.00$ \\
L. helveticus in SM & $10.63^{\mathrm{aA}} \pm 0.05$ & $7.11^{\mathrm{cB}} \pm 0.02$ & $4.28^{\mathrm{cC}} \pm 0.00$ & $4.28^{\mathrm{bD}} \pm 0.02$ & $4.06^{\mathrm{bE}} \pm 0.08$ \\
L. helveticus in GG & $9.90^{\mathrm{cA}} \pm 0.07$ & $4.57^{\mathrm{dB}} \pm 0.03$ & $0.00^{\mathrm{dC}} \pm 0.00$ & $0.00^{\mathrm{dC}} \pm 0.00$ & $0.00^{\mathrm{cC}} \pm 0.00$ \\
\hline
\end{tabular}

* The experimental values (means \pm SD) followed by different small letters a-d (within rows) and capital letters A-D (within columns) are significantly different $(p<0.05)$. a Bifidobacterium longum lyophilized in skim milk (SM) or gelatin/glycerol (GG) medium. ${ }^{b}$ Lactobacillus helveticus lyophilized in skim milk (SM) or gelatin/glycerol (GG) medium.

\subsection{Chemical Evaluation of the Stored Potato Chips}

At the end of the storage time, the oil content of the different samples of probiotic potato chips and probiotic-free bags (control) was determined (Figure 1). The oil content ranged between $23.67 \%$ to $24.79 \%$. Remarkably, there was no significant $(p>0.05)$ difference in the oil content values between probiotic products that contained both strains in all cryoprotective media. The significant difference was observed between B. longum (in SM medium), L. helveticus (in GG medium) with control bags, which is not biologically meaningful (1-1.12\%).

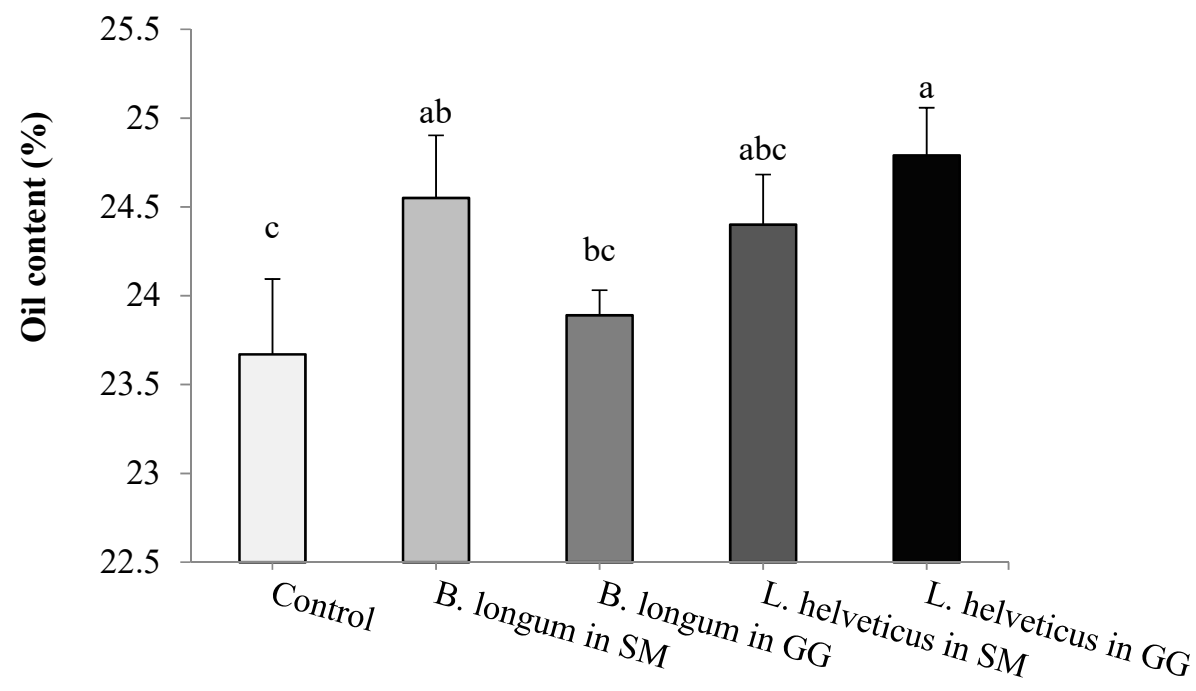

Probiotic potato chips samples

Figure 1. Oil content in different probiotic potato chips samples. Potato chips containing probiotic Bifidobacterium longum and Lactobacillus helveticus (lyophilized in skim milk or gelatin/glycerol medium) or without LAB (control), were analyzed after storage at $30^{\circ} \mathrm{C}$ for 4 months. a-d Different letters in the columns differ significantly $(p<0.05)$. 
The primary products of lipid oxidation are hydroperoxides. Therefore, PV is an importance index to assess the level of lipid oxidation in products containing oils during storage. It reflects the amount of hydro peroxides and secondary oxidation products (ketones and aldehydes) in fat [55]. Peroxide value (PV) of the extracted oil was determined in all samples and represented in Figure 2. Although there were no significant differences in oil content of different probiotic chip samples (Figure 1), the probiotic LAB strain and the lyophilization medium significantly affected the PV values. Interestingly, PV was significantly reduced by $40.13 \%$ and $35.47 \%$ in bags containing Bifidobacterium longum and Lactobacillus helveticus lyophilized in SM medium, respectively, compared to the control bags (38.85 meq $\mathrm{O}_{2} / \mathrm{kg}$ ). In GG medium, lyophilized B. longum strain decreased PV by 19\%. This could be explained as this strain remained alive for 4 months in an adequate population. In contrast, the highest PV value was recorded by Lactobacillus helveticus in GG medium (1.71 times higher than the control chips). The explanation of that high increment could be explained as L. helveticus is hydrogen peroxide-producing strain [56]. It may be highly producing $\mathrm{H}_{2} \mathrm{O}_{2}$ during storage in $\mathrm{GG}$ medium. Hydrogen peroxide is known as an oxidizer [57] and can promote the oxidation of potato chips' oil. On the other side, the antioxidant activity of Bifidobacterium longum to inhibit lipid oxidation was proven by many researchers [58,59]. They explained that activity by the fact that the Bifidobacterium longum strain may secrete an extensive amount of polyphenolic and phenolic compounds that minimized lipid oxidation. In an earlier study, PV ranged from 0.12 to 7.4 meq $\mathrm{O}_{2} / \mathrm{kg}$ fat during two months storage of fried potato crisps at room temperature, which was recorded by Abong et al. [9]. Rababah et al. [12] using grape seed extracts at $1000 \mathrm{ppm}$ minimized the peroxide value development in potato chips during 90 days of storage.

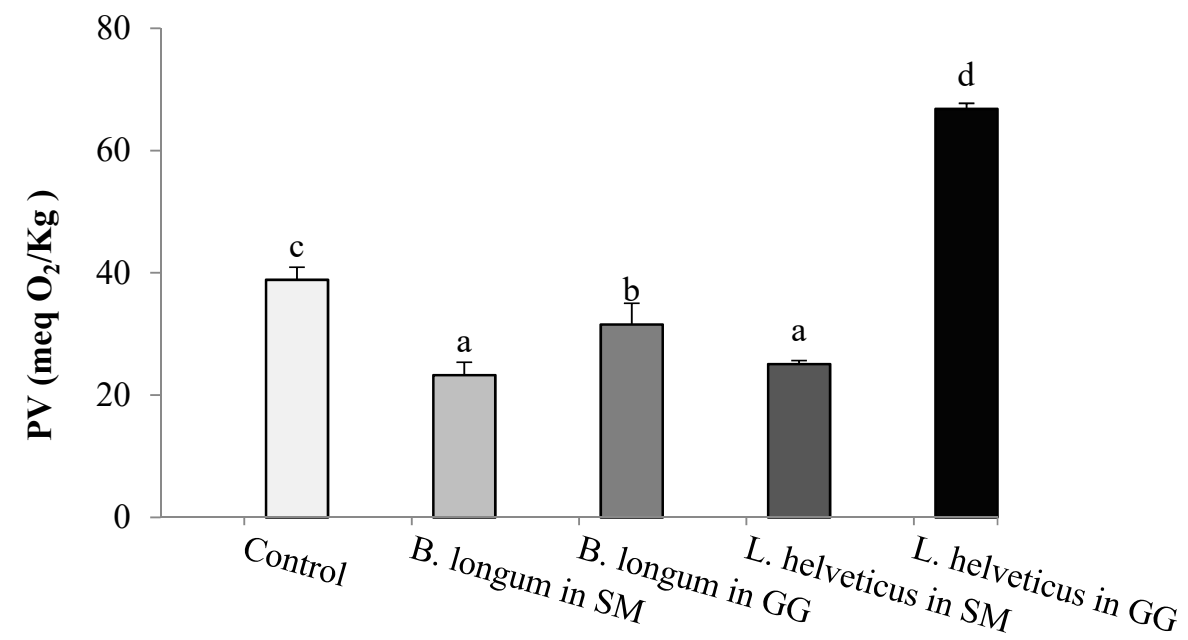

Probiotic potato chips samples

Figure 2. Peroxide value (PV) of the extracted oil from different probiotic potato chips samples. Potato chips containing probiotic Bifidobacterium longum and Lactobacillus helveticus (lyophilized in skim milk or gelatin/glycerol medium) or without LAB (control), were analyzed after storage at $30{ }^{\circ} \mathrm{C}$ for 4 months. a-d Different letters in the columns differ significantly $(p<0.05)$.

Acid value (AV) indicates the amount of free fatty acids in the food products and is a sign of oil stability during storage. High AV may cause diarrhea, gastrointestinal discomfort, and even liver damage [60]. In the present study, results in Figure 3 revealed that by lyophilization in SM media, B. longum was the most effective in minimizing free fatty acid formation in potato chips, followed by L. helveticus. Gelatin/glycerol (GG) medium has a negative effect on AV, as chips containing B. longum and L. helveticus formed the most significant FFA percent values $(3.22 \%, 5.98 \%$, respectively) in potato chip bags. Abong et al. [9] reported a significant increase in free fatty acid content in fried potato crisps during storage at room temperature $\left(25-30{ }^{\circ} \mathrm{C}\right)$ for a total period of 24 weeks. No previous research was conducted to evaluate probiotic lactic acid bacteria in minimizing the peroxide or acid value in potato chips. 


\subsection{Sensory Evaluation of the Stored Potato Chips}

Deep frying of potato chips gives them a unique appearance, flavors and texture, leading to a highly palatable product [55]. The mean values of the sensory characteristics of different potato samples are shown in Figure 4. Probiotic potato chips products were found acceptable by the consumers. By increasing the storage time, the sensory evaluation showed significant differences $(p<0.05)$ between the analyzed samples. Although the packed potato chips containing B. longum and L. helveticus in GG medium had the highest taste and overall acceptability scores at the experiment commencement, it declined to the lowest scores after the fourth month of storage, especially in bags containing L. helveticus in GG medium (overall acceptability score of 4.1). Overall, chips containing B. longum and L. helveticus in SM medium had the highest scores for taste, odor and overall acceptability for the next 3 months compared to chips without LAB (control). The greatest overall acceptability, taste and odor scored by B. longum in SM medium may be correlated to its viability and low PV and AV scores after 4 months of storage. In contrast, the decrease in sensory scores in bags containing B. longum and L. helveticus in GG medium may be related to the off-flavors released during storage. This is probably due to the formed free fatty acids and peroxides in the absence of viable probiotic cells. That means it is technically possible to incorporate B. longum into potato chips bags to preserve its quality during the shelf life.

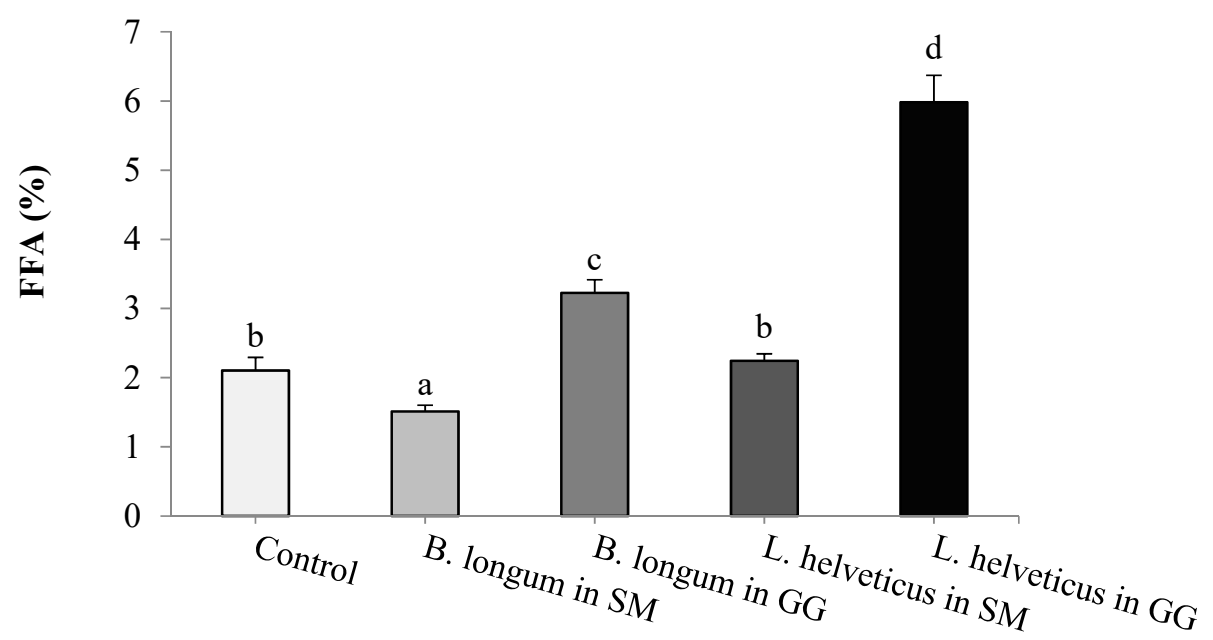

Probiotic potato chips samples

Figure 3. Acid value (AV) as free fatty acid (FFA) percent of the extracted oil from different probiotic potato chips samples. Potato chips containing probiotic Bifidobacterium longum and Lactobacillus helveticus (lyophilized in skim milk or gelatin/glycerol medium) or without LAB (control), were analyzed after storage at $30^{\circ} \mathrm{C}$ for 4 months. a-d Different letters in the columns differ significantly $(p<0.05)$.

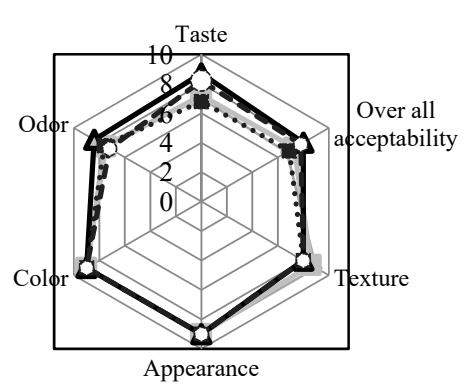

(a)

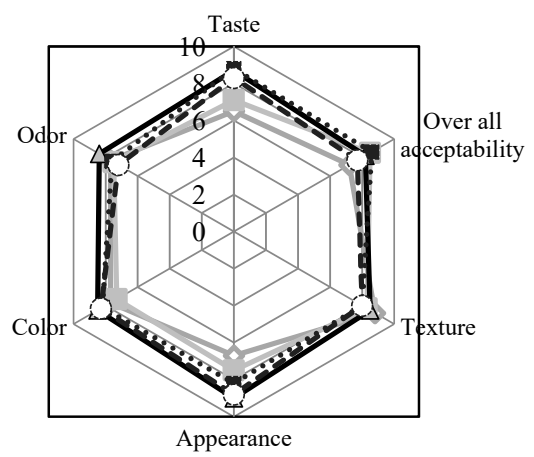

(b)

Figure 4. Cont. 
(c)
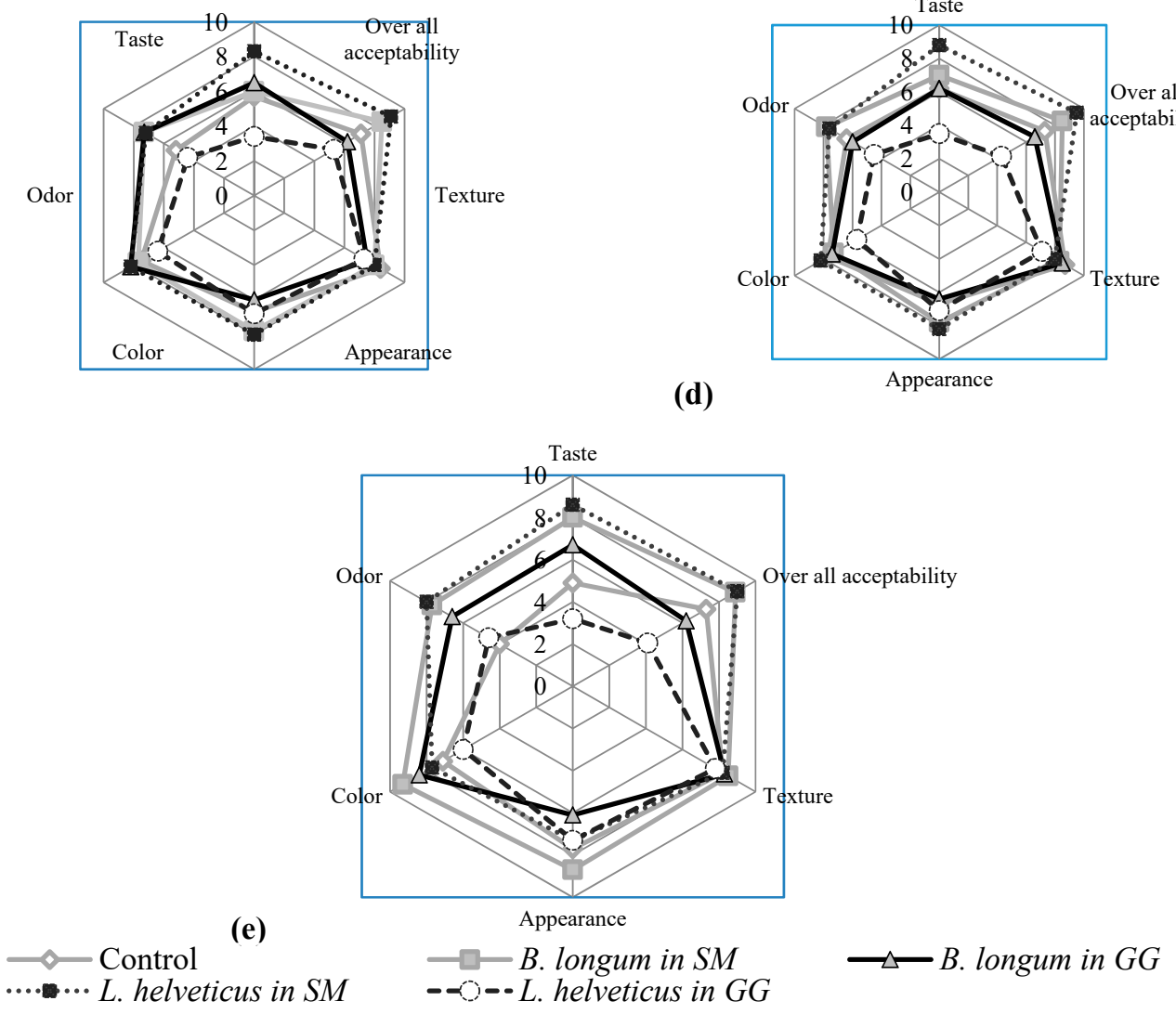

Figure 4. Sensory evaluation of probiotic potato chips during storage for 4 months at $30^{\circ} \mathrm{C}$. (a) At zero time, (b) After storage for one month, (c) After storage for two months, (d) After storage for three months and (e) After storage for four months.

\section{Conclusions}

Two cryoprotective media were compared to evaluate their suitability for probiotic lactic acid lyophilization and its protective effect in potato chips. GG and SM media were the most suitable for protecting Bifidobacterium longum and Lactobacillus helveticus, respectively. On the other side, potato chips proved a suitable vehicle for probiotics. Skim milk medium seemed to be the most useful medium in probiotic potato chip production, due to high recorded viability maintenance. Among the tested probiotics, Bifidobacterium longum was the best strain, as it preserved its viability at $10^{6} \mathrm{CFU} / \mathrm{g}$ for 4 months, and decreased the PV and AV of oil in potato chips. As this strain could limit excessive amounts of reactive radicals in vivo, it may contribute to prevent and control several diseases associated with oxidative stress and over-consumption of potato chips. Potato chips containing B. longum have promising characteristics, with improved stability and sensory characteristics to meet the preferences and demands of consumers. In conclusion, we recommend consuming such invented product in moderation to benefit from the probiotics with their antiobesity influence without impairment to human body.

Funding: This research received no external funding.

Conflicts of Interest: The author declares no conflict of interest. 


\section{References}

1. Yodkraisri, W.; Bhat, R. Quality evaluation of deep fried chips produced from lotus rhizome. Int. Food Res. J. 2012, 19, 1423-1427.

2. Archana, G.; Babu, P.A.; Sudharsan, K.; Sabina, K.; Raja, R.P.; Sivarajan, M. Evaluation of fat uptake of polysaccharide coatings on deep-fat fried potato chips by confocal laser scanning microscopy. Int. J. Food Prop. 2016, 19, 1583-1592. [CrossRef]

3. Miller, D.L.; Castellanos, V.H.; Shide, D.J.; Peters, J.C.; Rolls, B.J. Effect of fat-free potato chips with and without nutrition labels on fat and energy intakes. Am. J. Clin. Nutr. 1998, 68, 282-290. [CrossRef]

4. Allam, S.S.; El-Sayed, F.E. Fortification of fried potato chips with antioxidant vitamins to enhance their nutritional value and storage ability. Gras. Aceit. 2004, 55, 434-443.

5. Pedrischi, F.; Mery, D.; Marique, T. Quality Evaluation and Control of Potato Chips and French Fries. In Computer Vision Technology for Food Quality Evaluation; Sun, D., Ed.; Academic Press, Elsevier: Oxford, UK, 2008; pp. 545-566.

6. Beals, K.A. Potatoes, nutrition and health. Am. J. Potato Res. 2019, 96, 102-110. [CrossRef]

7. Liska, D.; Cook, C.; Wang, D.; Szplka, J. Millard reaction products and potatoes: Have the benefits been clearly assessed? Food Sci. Nutr. 2015, 4, 234-249. [CrossRef]

8. Joshi, A.; Rudra, S.G.; Sagar, V.R.; Raigond, P.; Dutt, S.; Singh, B. Development of low fat potato chips through microwave processing. J. Food Sci. Technol. 2016, 53, 3296-3303. [CrossRef]

9. Abong, G.O.; Okoth, M.W.; Imungi, J.K.; Kabira, J.N. Effect of slice thickness and frying temperature on color, texture and sensory properties of crisps made from four Kanyan potato cultivars. Am. J. Food Technol. 2011, 6, 753-762. [CrossRef]

10. Lin, X.; Xia, Y.; Wang, G.; Yang, Y.; Xiong, Z.; Lv, F. Lactic acid bacteria with antioxidant activities alleviating oxidized oil induced hepatic injury in mice. Front. Microbiol. 2018, 9, 2684. [CrossRef]

11. Makhoul, H.; Ghaddar, T.; Toufeili, I. Identification of some rancidity measures at the end of the shelf life of sunflower oil. Eur. J. Lipid Sci. Technol. 2006, 108, 143-148. [CrossRef]

12. Rababah, T.M.; Feng, H.; Yang, W.; Yucel, S. Fortification of potato chips with natural plant extracts to enhance their sensory properties and storage stability. J. Am. Oil Chem. Soc. 2012, 89, 1419-1425. [CrossRef]

13. FAO/WHO. Guidelines for the Evaluation of Probiotics in Food; FAO/WHO: London, ON, Canada, 2002; pp. 1-11. Available online: http://www.who.int/foodsafety/fs_management/en/probiotic_guidelines.pdf (accessed on 16 April 2020).

14. Giraffa, G. Lactobacillus helveticus: Importance in food and health. Front. Microbiol. 2014, 5, 338. [CrossRef] [PubMed]

15. Kerry, R.; Patra, J.K.; Gouda, S.; Park, K.; Shin, H.; Das, G. Benefaction of probiotics for human health. J. Food Drug Anal. 2018, 26, 927-939. [CrossRef] [PubMed]

16. Fenster, K.; Freeburg, B.; Hollard, C.; Wong, C.; Laursen, R.R.; Ouwehand, A.C. The production and delivery of probiotics: A review of a practical approach. Microorganisms 2019, 7, 83. [CrossRef] [PubMed]

17. Rivera-Espinoza, Y.; Gallardo-Navarro, Y. Non-dairy probiotic products. Food Microbiol. 2010, $27,1-11$. [CrossRef] [PubMed]

18. Gawkowski, D.; Chikindas, M.L. Non-dairy probiotic beverages: The next step into human health. Benefic. Micro. 2013, 4, 127-142. [CrossRef] [PubMed]

19. Reddy, S.B.; Rivenson, A. Inhibitory effect of Bifidobacterium longum on colon, mammary, and liver carcinogenesis induced by 2-amino-3-methylimidazo [4,5-f] quinoline, a food mutagen. Cancer Res. 1993, 53, 3914-3918.

20. Tang, W.; Xing, Z.; Hu, W.; Li, C.; Wang, J.; Wang, Y. Antioxidative effects in vivo and colonization of Lactobacillus plantarum MA2 in the murine intestinal tract. Appl. Microbiol. Biotechnol. 2016, 100, 7193-7202. [CrossRef]

21. Kumar, R.S.; Kanmani, P.; Yuvaraj, N.; Paari, K.A.; Pattukumar, V.; Thirunavukkarasu, C. Lactobacillus plantarum AS1 isolated from south Indian fermented food Kallappam suppress 1,2-dimethyl hydrazine (DMH)-induced colorectal cancer in male Wister rats. Appl. Biochem. Biotechnol. 2012, 166, 620-631. [CrossRef]

22. Namdari, A.; Nejati, F. Development of antioxidant activity during milk fermentation by wild isolates of Lactobacillus helveticus. Appl. Food Biotechnol. 2016, 3, 178-186. 
23. Elfahri, K.R.; Vasiljevic, T.; Yeager, T.; Donkor, O.N. Anti-colon cancer and antioxidant activities of bovine skim milk fermented by selected Lactobacillus helveticus strains. J. Dairy Sci. 2016, 99, 31-40. [CrossRef] [PubMed]

24. Skrzypczak, K.; Gustaw, W.; Kononiuk, A.; Sołowiej, B.; Waśko, A. Estimation of the antioxidant properties of milk protein preparations hydrolyzed by Lactobacillus helveticus T80, T105 and B73. Czech J. Food Sci. 2019, 37, 260-267. [CrossRef]

25. Song, M.; Van-Ba, H.; Park, W.; Yoo, J.; Kang, H.; Kim, J.; Kang, S.; Kim, B.; Oh, M.; Ham, J. Quality characteristics of functional fermented sausages added with encapsulated probiotic Bifidobacterium longum KACC 91563. Korean J. Food Sci. Anim. Resour. 2018, 38, 981-994. [CrossRef] [PubMed]

26. An, H.M.; Park, S.Y.; Lee, D.K.; Kim, J.R.; Cha, M.K.; Lee, S.W.; Lim, H.T.; Kim, K.J.; Ha, N.J. Antiobesity and lipid-lowering effects of Bifidobacterium spp. in high fat diet-induced obese rats. Lipids Health Dis. 2011, 10, 116. [CrossRef]

27. Yin, Y.; Yu, Q.; Fu, N.; Liu, X.; Lu, F. Effects of four Bifidobacteria on obesity in high-fat diet induced rats. World J. Gastroenterol. 2010, 16, 3394-3401. [CrossRef]

28. Chen, J.J.; Wang, R.; Li, X.F.; Wang, R.L. Bifidobacterium longum supplementation improved high-fat-fed-induced metabolic syndrome and promoted intestinal Reg I gene expression. Exp. Biol. Med. 2011, 236, 823-831. [CrossRef]

29. Arigoni, F.; Darimont-Nicolau, C.; Mace, C. Lactobacillus helveticus CNCM I-4095 and Weight Control. U.S. Patent 8,454,949, 4 June 2013.

30. Guergoletto, K.B. Dried Probiotics for Use in Functional Food Applications. In Food Industrial Processes-Methods and Equipment; Valdez, B., Ed.; InTech Open: London, UK, 2012; pp. 227-251.

31. Oyinloye, T.M.; Yoon, W.B. Effect of freeze-drying on quality and grinding process of food produce: A review. Processes 2020, 8, 354. [CrossRef]

32. Saez-Lara, M.; Gomez-Liorente, C.; Plaza-Diaz, J.; Gil, A. The role of probiotic lactic acid bacteria and Bifidobacteria in the prevention and treatment of inflammatory bowel disease and other related diseases: A systematic review of randomized human clinical trials. Biomed. Res. Int. 2015, 2015, 505878. [CrossRef]

33. Klingberg, T.D.; Budde, B.B. The survival and persistence in the human gastrointestinal tract of five potential probiotic Lactobacilli consumed as freeze-dried cultures or as probiotic sausage. Int. J. Food Microbiol. 2006, 109, 157-159. [CrossRef]

34. Chen, M.; Mustapha, A. Survival of freeze-dried microcapsules of $\alpha$-galactosidase producing probiotics in a soy bar matrix. Food Microbiol. 2012, 30, 68-73. [CrossRef]

35. Li, C.U.I.; Niu, L.Y.; Li, D.J.; Liu, C.Q.; Liu, Y.P.; Liu, C.J.; Song, J.F. Effects of different drying methods on quality, bacterial viability and storage stability of probiotic enriched apple snacks. J. Integr. Agric. 2018, 17, 247-255.

36. Saarela, M.; Virkajarvi, I.; Alakomi, H.; Sigvart-Mattila, P.; Matto, J. Stability and functionality of freeze-dried Bifidobacterium cell during storage in juice milk. Int. Dairy J. 2006, 16, 1477-1482. [CrossRef]

37. Terpou, A.; Mantzourani, I.; Galanis, A.; Kanellaki, M.; Bezirtzoglou, E.; Bekatorou, A.; Koutinas, A.A.; Plessas, S. Employment of L. paracasei K5 as a novel potentially probiotic freeze-dried starter for feta-type cheese production. Microorganisms 2019, 7, 3. [CrossRef] [PubMed]

38. Dimitrellou, D.; Kandylis, P.; Kourkoutas, Y. Assessment of freeze-dried immobilized Lactobacillus casei as probiotic adjunct culture in yogurts. Foods 2019, 8, 374. [CrossRef] [PubMed]

39. Zyzelewicz, D.; Nebesny, E.; Motyl, I.; Libudzisz, Z. Effect of milk chocolate supplementation with lyophilized Lactobacillus cells on its attributes. Czech J. Food Sci. 2010, 5, 392-406. [CrossRef]

40. Gadhiya, D.; Shah, N.P.; Patel, A.R.; Prajapati, J.B. Preparation and shelf life study of probiotic chocolate manufactured using Lactobacillus helveticus MTCC 5463. Acta Aliment. 2018, 47, 350-358. [CrossRef]

41. Lim, J.; Yoon, S.; Tan, P.; Yang, S.; Kim, S.; Park, H. Probiotic properties of Lactobacillus plantarum LRCC5193, a plant-origin lactic acid bacterium isolated from Kimchi and its use in chocolates. J. Food Sci. 2018, 83, 2802-2811. [CrossRef]

42. Petukhov, I.; Malcolmson, L.J.; Przybylski, R.; Armstrong, L. Storage stability of potato chips fried in genetically modified canola oils. J. Am. Oil Chem. Soc. 1999, 76, 889-896. [CrossRef]

43. Trsic-Milanovic, N.; Kodzie, A.; Baras, J.; Dimitrijevic-Brankovic, S. The influence of a cryoprotective medium containing glycerol on the lyophilization of lactic acid bacteria. J. Serbian Chem. Soc. 2001, 66, 435-440. [CrossRef] 
44. Yeo, S.; Shin, H.S.; Lee, H.W.; Hong, D.; Park, H.; Holzapfel, W. Determination of optimized growth medium and cryoprotective additives to enhance the growth and survival of Lactobacillus salivarius. J. Microbiol. Biotechnol. 2018, 28, 718-731. [CrossRef]

45. Association of Official Agricultural Chemicals (AOAC). Official Methods of Analysis; AOAC International: Washington, DC, USA, 2005.

46. Ludwig, T.G.; Rochester, N.Y. The anthrone method for the determination of carbohydrates in foods and in oral rinsing. J. Dent. Res. 1956, 35, 90-94. [CrossRef] [PubMed]

47. Miller, G.L. Use of dinitrosalisylic acid reagent for determination of reducing sugar. Anal. Chem. 1959, 31, 426-428. [CrossRef]

48. Paquot, C. Standard Methods for the Analysis of Oils, Fats and Derivatives, 6th ed.; Pergamon Press, Elsevier: Oxford, UK, 1979.

49. Atalay, A.; Inanc, A. Stability of sunflower oil enriched with olive phenolics in deep frying condition. J. Agric. Fac. Gaziosmanpasa Univ. 2018, 35, 152-163.

50. Sharma, R.; Sonodiya, B.S.; Thakur, G.S.; Jaiswal, P.; Sharma, A.; Bisen, P.S. Standardization of lyophilization medium for Streptococcus thermophiles subjected to viability escalation on freeze drying. Microbiol. Res. 2014, 5, 1-3. [CrossRef]

51. Parra, K.; Ferrer, M.; Pinero, M.; Barboza, Y.; Medina, L.M. Use of Lactobacillus acidophilus and Lactobacillus casei for a potential probiotic legume-based fermented product using pigeon pea (Cajanus cajan). J. Food Protect. 2013, 76, 265-271. [CrossRef]

52. Nebesny, E.; Zyzelewicz, D.; Libudzisz, Z. Dark chocolates supplemented with Lactobacillus strains. Eur. Food Res. Technol. 2007, 225, 33-42. [CrossRef]

53. Simpson, P.J.; Stanton, C.; Fitzgerald, G.F.; Ross, R.P. Intrinsic tolerance of Bifidobacterium species to heat and oxygen and survival following spray drying and storage. J. Appl. Microbiol. 2005, 99, 493-501. [CrossRef]

54. Mirkovic, M.; Seratlic, S.; Kilcawley, K.; Mannion, D.; Mirkovic, N.; Radulovic, Z. The sensory quality and volatile profile of dark chocolate enriched with encapsulated probiotic Lactobacillus plantarum bacteria. Sensors 2018, 18, 2570. [CrossRef]

55. Halagarda, M.; Suwała, G. The quality of salted potato chips available on the polish market. Zeszyty Naukowe. Uniw. Ekonom. Krak. 2016, 8, 71-86. [CrossRef]

56. Taverniti, V.; Guglielmetti, S. Health-promoting properties of Lactobacillus helveticus. Front. Microbiol. 2012, 3, 392. [CrossRef]

57. Miochowski, J.; Peczyska-Czoch, W.; Pietka-Ottlik, M.; Wojtowicz-Miochowska, H. Non-metal and enzymatic catalysts for hydroperoxide oxidation of organic compounds. Open Cat. J. 2011, 4, 54-82. [CrossRef]

58. Lin, M.; Yen, C. Inhibition of lipid peroxidation by Lactobacillus acidophilus and Bifidobacterium longum. J. Agric. Food Chem. 1999, 47, 3661-3664. [CrossRef] [PubMed]

59. Shen, Q.; Shang, N.; Li, P. In vitro and in vivo antioxidant activity of Bifidobacterium animalis D1 isolated from centenarians. Curr. Microbiol. 2011, 62, 1077-1103. [CrossRef] [PubMed]

60. Zhang, W.; Li, N.; Feng, Y.; Su, S.; Li, T.; Liang, B. A unique quantitative method of acid value of edible oils and studying the impact of heating on edible oils by UV-Vis spectrometry. Food Chem. 2015, 185, 326-332. [CrossRef]

(C) 2020 by the author. Licensee MDPI, Basel, Switzerland. This article is an open access article distributed under the terms and conditions of the Creative Commons Attribution (CC BY) license (http://creativecommons.org/licenses/by/4.0/). 